\section{Polymer derived ceramic foams with additional strut porosity}

VERENA RESCHKE - Otto-von-Guericke University of Magdeburg (OMa),

ALEXANDRA LASKOWSKY - OMa, Institute for Materials and Joining Technology Mathias KAPPA - Brandenburg University of Technology, Light Weight Ceramics Group KAISHI WANG - University of Washington (UW), Department of Materials Science and Engineering RAJENDRA K. BORDIA - UW, Department of Materials Science and Engineering MichaEL SCHEFFLER - OMa, Institute for Materials and Joining Technology - m.scheffler@ovgu.de Received: 28.02.2011. - Érkezett: 2011.02.28. http://dx.doi.org/10.14382/epitoanyag-jsbcm.2011.10

Ceramic foams with additional strut porosity were prepared by a self-foaming process of a polysilsesquioxane. The strut porosity was generated by adding sacrificial pore formers comprising of polymethylmethacrylate or of polyethylene to the self-foaming silicone. The polymer-inherent shrinkage was reduced by adding $\mathrm{SiC}$ particulate fillers to the silicone/pore-former mixture. Foaming was carried out on a preheated furnace at $270^{\circ} \mathrm{C}$, and subsequent pyrolysis was performed in argon atmosphere in the temperature range from $800^{\circ} \mathrm{C}$ to $1200^{\circ} \mathrm{C}$ in order to trigger the polymer-to-ceramic transformation of the polysilsesquioxane. The materials were characterized with respect to the pore size and the total porosity, the microstructure and the mechanical strength. The volumetric mean pore diameter of the strut ranged from $25 \mu \mathrm{m}$ to 100 $\mu \mathrm{m}$ and the porosity was found to be $40 \%$ to $94 \%$. The maximum compression strength exceeded $16 \mathrm{MPa}$.

Keywords: ceramic foams, preceramic polymers, self-foaming process, sacrificial pore formers
Verena RESCHKE

studied chemistry at the University of Oldenburg, Germany, and received her degree (Dipl. Chem.) in 2009. She is a Ph.D. student in the research group for Ceramic Materials at the Institute of Materials and Joining Technology, Otto-von-Guericke University of Magdeburg $(\mathrm{OMa})$, Germany. Presently, she is working on the fabrication of nanosized polymeric and ceramic materials.

Alexandra LASKOWSKY received a diploma degree in chemical engineering from the OMa in 2009. She is Ph.D. candidate in the research group for Ceramic Materials at the Institute of Materials and Joining Technology at $\mathrm{OMa}$. Her research is focused on coating of ceramics and metals with preceramic polymers.

Mathias KAPPA studied physics at Brandenburg Technical University, Cottbus, Germany (BTU). He received his Diploma degree in 2005. In 2007 he started a Ph.D. study at the BTU developing ceramic coatings on metals. In 2011 he joined the department of medical physics at the Carl-ThiemKlinikum GmbH, Cottbus, Germany, and is in charge for medical computertomography.

\section{Introduction}

Due to their outstanding properties such as high porosity, low thermal conductivity, high permeability, high temperature stability, chemical inertness, excellent thermal shock resistance, low dielectric constant, etc., ceramic foams have gained increasing interest during the past fifteen years or so. Therefore, the foams are considered for a wide range of technological applications such as filters, membranes, absorbents, catalytic substrates, thermal insulation, gas burner media, refractory materials, lightweight structural panels, reinforcement for polymer or metal composites and biomedical devices [1-5]. Novel developments are dedicated to the manufacturing of high-transparent glass foams for optical applications such as biological cell support or support for photocatalysts $[6,7]$. The most relevant processing routes for the fabrication of porous ceramics are (i) replica techniques [8-10], (ii) direct-foaming techniques [11-16] and (iii) sacrificial template methods [1719].

In this work, $\mathrm{SiC}$ filled polymer derived ceramic foams with additional strut porosity were manufactured by the addition of polymethylmethacrylat (PMMA) or polyethylene (PE) as sacrificial pore formers to a polysilsesquioxane with structure terminating hydroxyl and ethoxy groups. When heat is applied in the temperature range between $220^{\circ} \mathrm{C}$ and $300^{\circ} \mathrm{C}$ condensation of the aforementioned functional groups occurs resulting in (i) the formation of water and ethanol, (ii) the formation of foam bubbles and (iii) the increase of the viscosity which actually prevents the foam from collapsing. As a result, a foamed thermoset silicone is obtained [12]. In contrast to previous work, in this work the foamed mixture comprises of the artificial burn-outs, additionally, which are more or less homogeneously distributed in the struts. The burn-out is intended to leave behind additional porosity in the struts.
Kaishi WANG

received a Ph.D. degree in Materials Science \& Engineering/Nanotechnology from the University of Washington, Seattle, WA, USA (UW), in 2010. His research interests mainly focus on polymer derived ceramics and ceramic matrix composites for high-temperature and harsh environment applications. Currently, he is a postdoctoral research associate at UW, working on the functional uses of preceramic polymers.

Rajendra K. BORDIA holds a Ph.D. degree in Materials Science \& Engineering. He is a professor in the Department of Materials Science \& Engineering at the UW. Among others, he is Fellow of the American Ceramic Society (2002) and was awarded the Alexander-von-Humboldt Research Award for Senior Scientist (2007). His research focuses on processing and properties of ceramics and composites with current focus on material systems for energy, environment and health.

Michael SCHEFFLER holds a Ph.D. degree in inorganic chemistry. He is a professor for Materials Technology and head of the Ceramic Materials group at $\mathrm{OMa}$. His research focuses on inorganic non-metallic materials with extended functionality for high-temperature and energy applications. He is in charge for the expert group of Cellular Materials of the Deutsche Gesellschaft fuer Materialkunde e. V. (DGM).

\section{Experimental procedure}

\section{Ceramic foam processing}

A methyl phenyl poly (silsesquioxane) (general formula [(C $\left.\left.{ }_{6} \mathrm{H}_{5}\right)_{0.62}\left(\mathrm{CH}_{3}\right)_{0.31}(\mathrm{OR})_{0.07} \mathrm{SiO}_{1.5}\right]_{\mathrm{n}}$ with $n \sim 20$, Silres H44, Wacker Chemie, Burghausen, Germany) which contains additional cross-linking active groups $\mathrm{R}=[-\mathrm{OH}]$ and $\left[-\mathrm{OC}_{2} \mathrm{H}_{5}\right]$ was used as preceramic polymer $[12,13]$. The polymer is solid at room temperature, has a melting interval at around $60^{\circ} \mathrm{C}$ and exhibits a density of $\sim 1 \mathrm{~g} / \mathrm{cm}^{3}$. The $\mathrm{H} 44$ was loaded with $\mathrm{SiC}$ (F800D, $\mathrm{d}_{50}=7,8-9,8 \mu \mathrm{m}$, ESK-SiC GmbH, Frechen, Germany). As sacrificial burn-out materials (strut-pore former) PMMA with a bead size of $50-150 \mu \mathrm{m}$, an average molecular weight (M.W.) of $35,000 \mathrm{~g} / \mathrm{mol}^{-1}$ and a density of $\rho=1.2 \mathrm{~g} / \mathrm{cm}^{-3}$ was used (Acros Organics, Geel, Belgium). The other pore former used in this work is ultra-high molecular weight polyethylene with three different particle size distributions (GUR ${ }^{\circ} \mathrm{UHMW}-\mathrm{PE}$, 
GUR-X143 with $d_{50}=20 \mu \mathrm{m}$, GUR-2126 with $d_{50}=30 \mu \mathrm{m}$ and GUR-4150-3 with a particle size $\mathrm{d}_{50}=60 \mu \mathrm{m}$; density of all samples $\rho=0.3 \mathrm{~g} / \mathrm{cm}^{-3}$; Ticona $\mathrm{GmbH}$, Oberhausen, Germany).

The preceramic polymer:SiC filler:burn-out materials were dry mixed in a weight ratio of 54:36:10 in an overhead mixer with grinding balls for $2 \mathrm{~h}$. The mixture was then filled in aluminum tubes and foamed at $270^{\circ} \mathrm{C}$ for $2 \mathrm{~h}$ in air in a preheated furnace. The next step was sintering in a tube furnace in argon atmosphere. The foams were fired at a heating rate of $3 \mathrm{~K} / \mathrm{min}^{-1}$ to $500^{\circ} \mathrm{C}$ and hold for $2 \mathrm{~h}$. Subsequently, the foams were further heated at $5 \mathrm{~K} / \mathrm{min}^{-1}$ to $800^{\circ} \mathrm{C}, 1000^{\circ} \mathrm{C}$ or $1200^{\circ} \mathrm{C}$ with a holding time of $2 \mathrm{~h}$. The cooling rate to room temperature was set to $5 \mathrm{~K} / \mathrm{min}^{-1}$. After pyrolysis, the foams were cut with a low-speed saw. The diameter of the samples was $20 \mathrm{~mm}$ and the height $25 \mathrm{~mm}$. A processing scheme is given in Fig. 1.

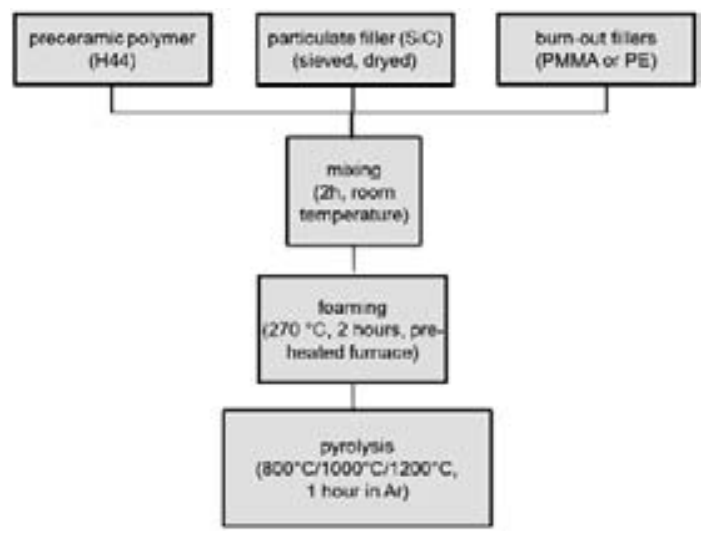

Fig.1. Processing scheme of the manufacturing of polymer derived ceramic foams by a self-foaming process with additional burn-outs for strut porosity generation

1. ábra Polimer alapú kerámia habok elóállitásra szolgáló, a porozitás növelését célzó, járulékos kiégéssel kombinált önhabosodási eljárás folyamatsémája

\section{Characterization}

Thermal analysis of the sacrificial templates as well of the samples was carried out with a STA 409 (NetzschGerätebau $\mathrm{GmbH}$, Selb, Germany). The green material was heated with 5 $\mathrm{K} / \mathrm{min}^{-1}$ to an end temperature of $1300^{\circ} \mathrm{C}$. The atmosphere was argon with a flow rate of $70 \mathrm{ml} / \mathrm{min}^{-1}$. The foam morphology was characterized using scanning electron microscopy (SEM JSM-7000, EDX - JEOL Ltd. Tokyo, Japan). Prior to analysis the samples were sputter-coated with platinum.

Porosity and pore size distribution of the pyrolyzed foams was measured by $\mathrm{Hg}$ intrusion with a MicromeriticsAutoPore IV 9500 (Micromeritics Corporate Headquarters, Norcross, GA, USA). From selected samples microcomputertomography $(\mu-\mathrm{CT})$ was carried out to investigate the cell morphology of the macroscopic cells with a Skyscan 1172 (Skyscan, Kontich, Belgium).

The compressive strength was determined at room temperature with the cylindrical samples having a height of $25 \mathrm{~mm}$ and a diameter of $20 \mathrm{~mm}$. A universal testing machine (Instron 4505, Instron, Norwood, MA, USA) was used with a constant crosshead speed of $1.5 \mathrm{~mm} / \mathrm{min}^{-1}$. From the maximum stress after elastic deformation the crushing strength of the foam was computed.

\section{Results and discussion}

Previous studies referring to synthesis parameters such as filler size, ratio of starting materials and foaming temperature showed a significant influence of these parameters on the effectiveness of the foaming process. The use of $\mathrm{SiC}$ filler particles with diameters of $0.6-0.9 \mu \mathrm{m}$, e.g., inhibits the foaming process. The obtained structures showed no macro porosity after the foaming procedure. To obtain foamed structures comparable to the unfilled system, filler particles with a particle size ranging from of 8 to $10 \mu \mathrm{m}$ have been used. A preceramic polymer to filler ratio of 60:40 wt\% showed good results in terms of foaming behavior. It was found that the maximum weight fraction of the sacrificial template should not exceed $10 \mathrm{wt} \%$ of the mixture. Especially in the case of PMMA a higher ratio led to an extremely high macro porosity with an inhomogeneous pore size distribution. Thus, foams were prepared with a polymer:SiC filler:burn-out template weight ratio of 54:36:10. X-ray diffraction analysis of foams pyrolysed up to $1200^{\circ} \mathrm{C}$ showed no crystalline phases beside that of $\mathrm{SiC}$ which was introduced as filler particles to minimize shrinkage. Therefore the obtained silicon oxycarbide (SiOC) ceramic structures have been assumed to be amorphous. In accordance to results in the literature phase separation and crystallization occur at temperatures above $1200^{\circ} \mathrm{C}[20]$.

\begin{tabular}{lc} 
Template & $\begin{array}{c}\mathbf{d}_{\mathbf{5 0}} \text { of burn-out template in } \boldsymbol{\mu m} \\
\text { (manufacturers data) }\end{array}$ \\
PMMA & $50-150$ (bead size) \\
\hline PE GUR-4150-3 & 60 \\
\hline PE GUR-2126 & 30 \\
\hline PE GUR-X143 & 20 \\
\hline
\end{tabular}

Table 1. Template sizes used to create additional strut porosity 1. táblázat A növelt porozitás kialakításhoz használt sablonok

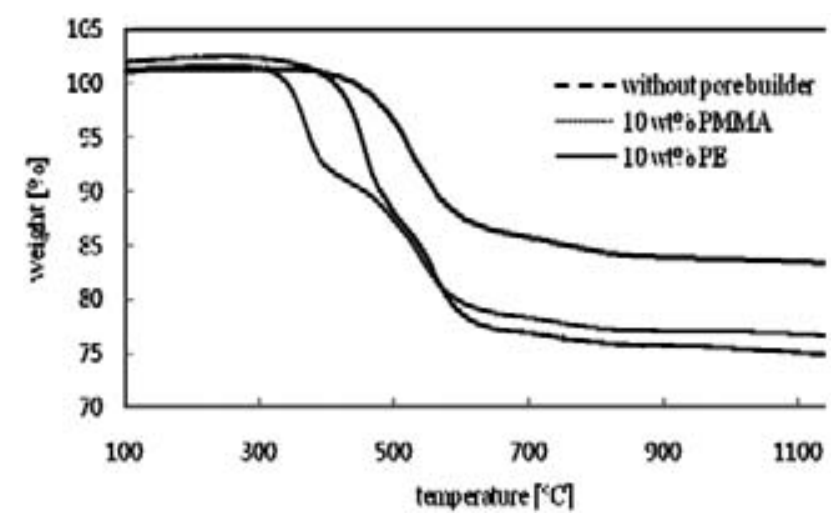

Fig. 2. Thermal gravimetric analysis of the as-synthesized foams

2. ábra Az eredetileg elóállitott habok termogravimetriás elemzése

Foams with additional strut porosity were prepared by using distinct pore formers made up of polymethylmethacrylate (PMMA) microbeads or ultra-high molecular weight polyethylene grains (PE), respectively. In the latter case, three different particle sizes were used (see Table 1). Thermal gravimetric analysis in argon revealed a total weight loss > $98 \mathrm{wt} \%$ for both types of raw materials. The decomposition of PMMA 
was found to start at about $280^{\circ} \mathrm{C}$ and was completed at $440^{\circ} \mathrm{C}$, whereas all $\mathrm{PE}$ types decomposed identically in a temperature range from about 440 to $500^{\circ} \mathrm{C}$. Fig. 2. shows a comparison in weight loss for foams prepared with and without pore former materials pyrolysed in argon up to $1200^{\circ} \mathrm{C}$. The heating rates were set in correspondence to the sintering process. The weight loss of the pore former-free foam was about $17 \mathrm{wt} \%$. Due to the removal of additional sacrificial templates, a higher weight loss of about $24 \%$ of the foam prepared with PMMA was found, whereas the total weight loss of PE containing foams was approximately $26 \mathrm{wt} \%$. Presumably, this small difference occurs due to incipient burn-out of PMMA during the foaming process in combination with decomposition at lower temperatures as compared to PE burn-outs. In general, the weight loss for PMMA and PE containing samples is in good agreement with theoretical values taking into account the nearly complete decomposition of the burn-out materials.

The different foams prepared with and without the addition of the sacrificial templates were imaged after sintering in argon at $1000^{\circ} \mathrm{C}$ using scanning electron microscopy. For the template-free approach (cf. Fig. 3a.), apart from the occurrence of cracks, large cells with dense struts were observed. As shown exemplarily in Fig. $3 b$. and $3 c$., the addition of pore formers led to an increased porosity in the struts. Detailed micrographs of the porous struts revealed that pore size and shape depend on the morphology of the sacrificial template. Large pores (i.e. spherical in shape) with diameters ranging from $40-150 \mu \mathrm{m}$ are formed when PMMA microspheres were employed (see
Fig. 4a.). However, further observations within the pores depict small spheres of about 1-10 $\mu \mathrm{m}$ after burn out of the PMMA and sintering (cf. Fig. 4b.). EDX analysis revealed no difference in elemental distribution compared to the surrounding SiOC amorphous ceramic structure.

We assume that low-molecular weight components from the preceramic polymer have interacted with PMMA during the low-temperature thermal processing prior to foaming, and spheres have been formed during condensation and crosslinking resulting in the $\mathrm{SiOC}$ spheres as found in these samples. However, for a deeper understanding further investigations are necessary.

In comparison, the addition of smaller PE particles such as GUR-2126 resulted in an increased number of irregular formed strut pores with diameters varying from $8-35 \mu \mathrm{m}$ (see Fig. 4c.). SEM analysis of pure GUR-2126 showed strongly aggregated and irregular formed particles in a similar size range as well. In general, after sintering the generated pore sizes are slightly smaller due to the shrinkage during polymer-to-ceramic conversion during pyrolysis.

Results from mercury intrusion porometry are shown in Fig. 5. Sintered samples formerly containing PMMA microbeads possess a volumic median pore diameter of about $100 \mu \mathrm{m}$, and a pore diameter of $9 \mu \mathrm{m}$ was found in foams containing GUR-2126. Strut porosities of sintered foams derived from the PE types GUR-X143 and GUR-4150-3 were estimated to possess volumetric median pore diameters of $25 \mu \mathrm{m}$ and 81 $\mu \mathrm{m}$, respectively.
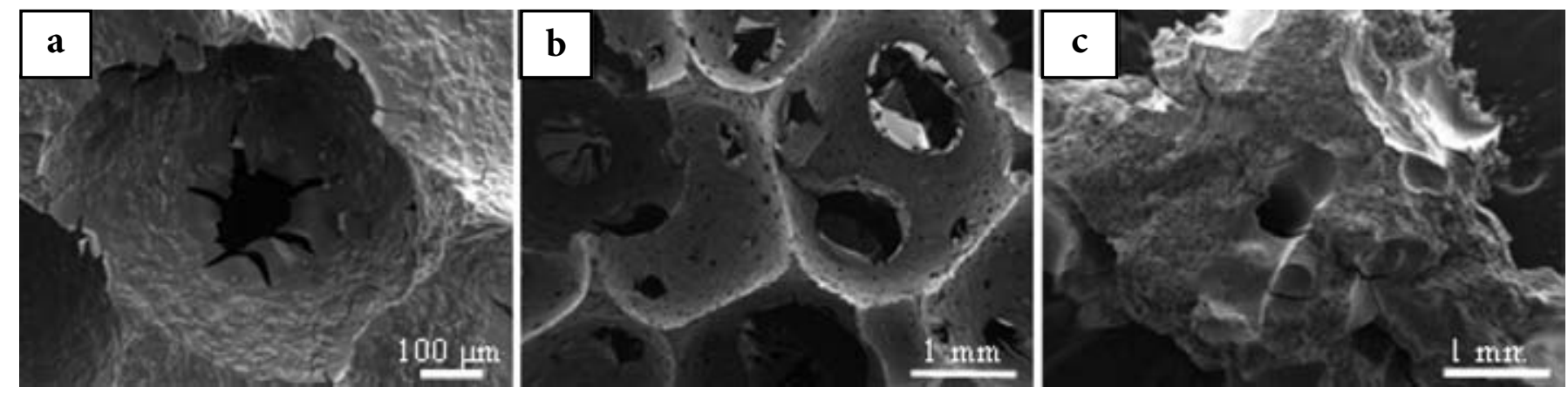

Fig. 3. SEM micrographs of the foam obtained after pyrolysis in argon at $1000^{\circ} \mathrm{C}$. a) no additional pore builder, b) with PMMA, and c) with PE-GUR-2126

3. ábra Az argonban, $1000^{\circ} \mathrm{C}$-on végzett pirolizissel készült habok SEM felvételei (a) további pórusképzö nélkül, (b) PMMA-val és (c) PE-GUR-2126-tal
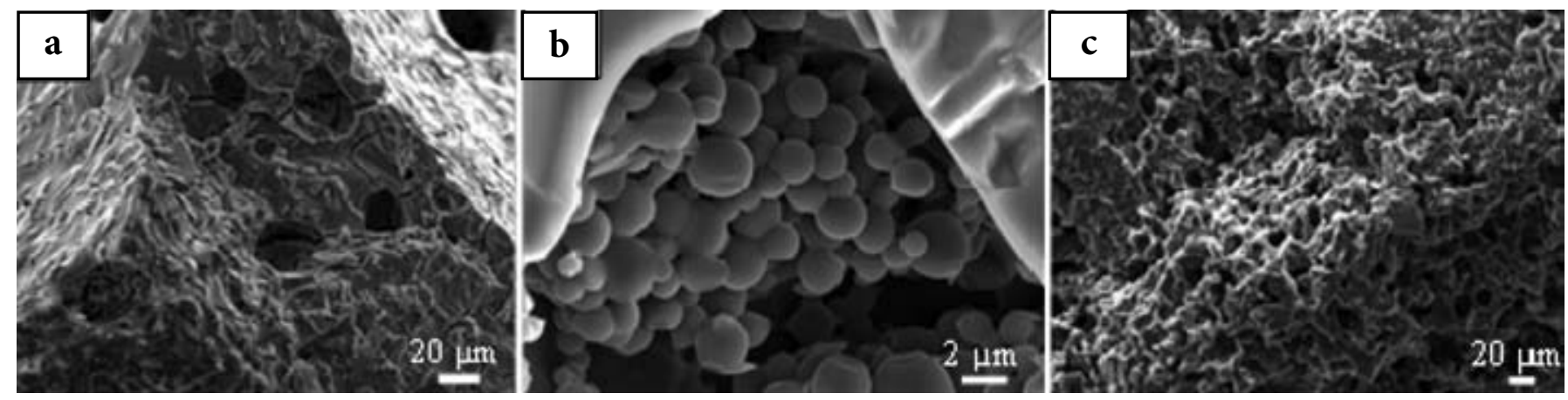

Fig. 4. SEM micrographs detailed view of structures obtained after burn-out of template and pyrolyzed in argon at $1000{ }^{\circ} \mathrm{C}$. a) Strut pores generated by PMMA, $b$ ) detailed view within a pore generated by PMMA c) porous strut generated by PE-GUR 2126

4. ábra A sablon kiégése és az argonban, $1000^{\circ} \mathrm{C}$-on végzett pirolizis után kapott termékek mikroszerkezetét mutató SEM felvételek (a) a PMMA-val kialakitott pórusok, (b) a PPMAval kialakitott pórusok részletes képe és (c) a PE-GUR-2126-tal kialakított pórusszerkezet 


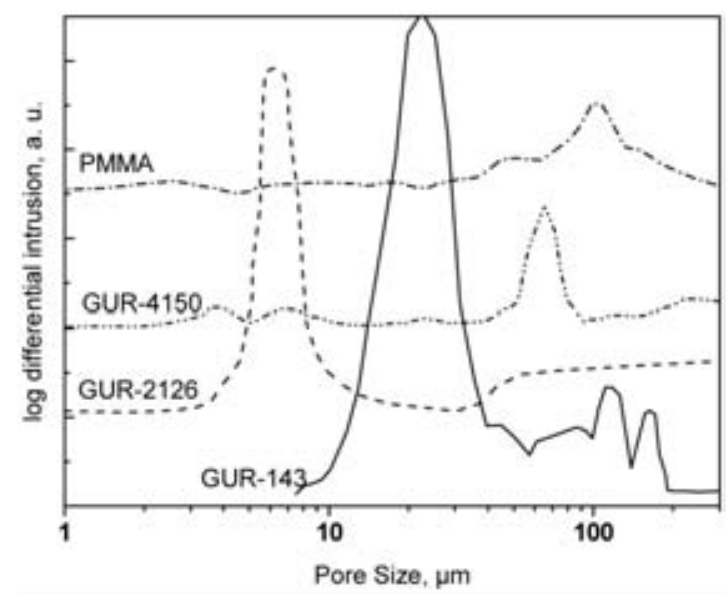

Fig. 5. Results of mercury intrusion for pore size distribution characterization of foams after pyrolysisat $1200^{\circ} \mathrm{C}$

5. ábra $\mathrm{Az} 1200^{\circ} \mathrm{C}$-on végzett pirolízis után higanypenetrációs módszerrel meghatározott pórusméret eloszlás

The influence of added sacrificial material on cell size distribution and total foam porosity was determined by Micro-CT-analysis $(\mu$-CT). Since obtained cell sizes were inhomogeneously distributed within the macrostructure, the samples were taken from a central part of the foam where a better degree of homogeneity was obvious. Fig. $6 a-6 c$. show 2D images of $\mu$-CT layers of sintered foams prepared with PMMA microbeads and two selected PE types. The addition of large PMMA microbeads led to a low number of relatively large pores. A total foam porosity of $51 \%$ was calculated. A $3 D$ reconstruction in two different resolutions is shown in Fig. $6 d$, e.

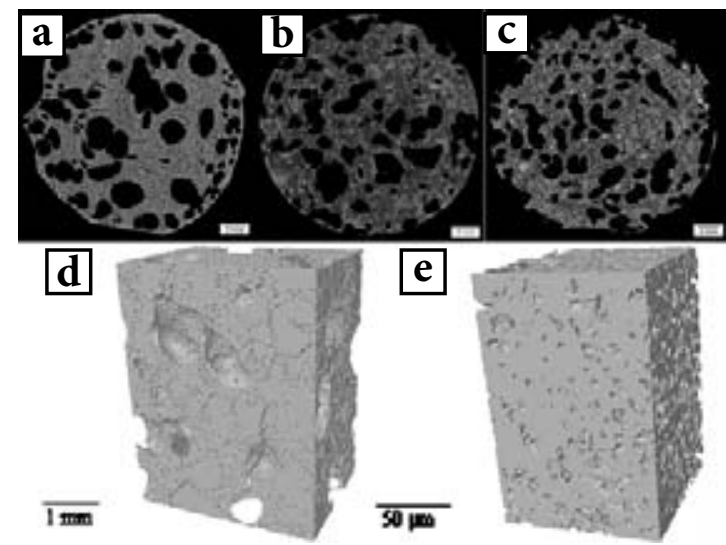

Fig. 6. $2 D \mu$-CT images of sintered foams. a) PMMA microbeads, b) PE GUR4150-3, c) PE GUR-2126; d) 3D reconstruction foams cells with GUR-2126generated strut porosity, e) $3 D$ reconstruction of a porous strut in higher resolution

6. ábra A szinterelt habok $2 D \mu$-CT módszerrel felvett képei. a) PMMA mikrogyöngyök, b) PE-GUR-4150-3, c) PE-GUR-2126; d) PE-GUR-2126-tal kialakitott pórusszerkezet $3 D$ rekonstruált képe, e) a pórusos szerkezet $3 D$ rekonstruált képe nagyobb felbontásban

Regarding the PE templates, a decrease of the PE particle size resulted in a lower total foam porosity accompanied by the occurrence of smaller cell sizes. GUR-4150-3 derived foams showed a total porosity of $54 \%$, whereas a porosity of $40 \%$ was measured using the PE template GUR-143-3 with the smallest particle sizes.

Compression tests of the different foams sintered in argon at temperatures from 800 to $1200^{\circ} \mathrm{C}$ showed a stepwise crushing behavior typical for ceramic foams. Fig. 7. shows exemplarily the stress-strain diagram for sintered foams prepared using the PMMA burn-outs. Compressive strength values of up to $12 \mathrm{MPa}$ were obtained. This is in good agreement with data from literature [13]. In comparison, the compressive strength for foams prepared with PE increased with increasing burn-out grain sizes of the template up to values of $16 \mathrm{MPa}$ using GUR-4150-3. However, an influence of the sintering temperature on the compressive strength was not detectable. Further investigations of template effects on formation of the macrostructure and total porosity are necessary.

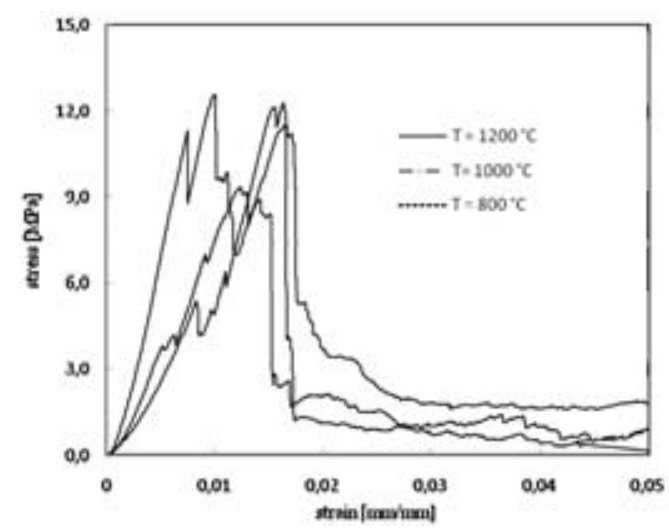

Fig. 7. Stress-strain diagram obtained from foams prepared with PMMA template and pyrolysis in argon at different temperatures

7. ábra PMMA sablonnal, és argonban, különböző hömérsékleteken végzett pirolizissel készült habok terhelés-feszültség görbéi

Finally it should be noticed that the obtained total porosities of $<55 \%$ derived from foams prepared in small aluminum tubes are rather low. When foaming is carried out in large containment the coalescence rate of the foamed material is significantly lower resulting in a higher porosity, typically between 80 and $95 \%$.

Fig. $8 a$. and $8 b$. show $2 \mathrm{D}$ images of $\mu-\mathrm{CT}$ of sintered foams produced in an aluminum tray of 10 by $15 \mathrm{~cm}$ in size without additional pore builder and with PMMA microbeads, respectively. Micro-CT calculations revealed a high total porosity of $90-94 \%$ for both. Samples prepared with PMMA showed a better pore distribution within the macrostructure with struts equally distributed compared to samples prepared without additional pore builders.

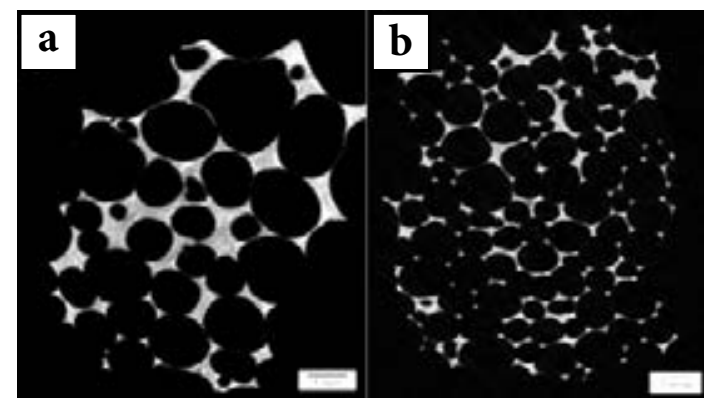

Fig. 8. $2 D \mu$-CT images of pyrolyzed foams prepared in an aluminum tray. a) without sacrificial template - $94 \%$ porosity; b) with PMMA microbeads sacrificial burn-outs - $90 \%$ porosity

8. ábra Alumínium vályúban pirolizált habok $2 D \mu$-CT módszerrel felvett képei a) sablon nélkül, 94\% porozitással, b) PMMA mikrogyöngyök kiégésekor, $90 \%$ porozitással 


\section{Conclusions}

Polymer derived ceramic foams with additional strut porosity were successfully fabricated by a direct foaming approach with a self-foaming polysiloxane and additional sacrificial burnouts comprising of PMMA or PE. The size and shape of the resulting pores in the struts can be controlled by altering the morphology of the sacrificial templates used in this approach. The polymer derived ceramic foams possessed total porosities ranging from $40 \%$ to $95 \%$, and compressive strength exceeded $16 \mathrm{MPa}$, depending on nature and size of the template, and on foaming containment, respectively.

\section{Acknowledgements}

The authors would like to thank the German Academic Exchange Service (DAAD) for financial support (D/08/11079). Sincere thanks for collaboration are given to Dr. Viola Wilker and Christiane Ohl of Light Weight Ceramics Group at the Brandenburg University of Technology Cottbus (Cottbus, Germany), and to Tuesday Kuykendall of the University of Washington, Seattle, WA, USA.

\section{References}

[1] Scheffler, M. - Colombo, P.: Cellular Ceramics: Structure, Manufacturing, Properties and Applications; WILEY-VCH Weinheim, Germany, 2005, ISBN 3-527-31320-6.

[2] Studart, A. R. - Gonzenbach, U. T. - Tervoort, E. - Gauckler, L.J.: Processing Routes to Macroporous Ceramics: A Review, J. Am. Ceram. Soc., 89 (2006), pp. 1771-1789.

[3] Colombo, P.: Conventional and novel processing methods for cellular ceramics, Phil. Trans. R. Soc. A, 364 (2006), pp. 109-124.

[4] Scheffler, M. - Scheffler, F.: Zeolite coatings on porous monoliths, Advances in Science and Technology, 45(2006), pp. 1260-1267.

[5] Scheffler, M. - Scheffler, F.: Processing of ceramic foams and their surface modification with zeolites, Ceramic Forum International 85 (2008), E45-E50.

[6] Ohl, C. - Kappa, M. - Wilker, V. - Bhattacharjee, S. - Scheffler, F. Scheffler, M.: Novel Open-Cellular Glass Foams for Optical Applications, J. Am. Ceram. Soc. 94 (2011), pp. 436-441.

[7] Bhattacharjee, S. - Das, P. R. - Ohl, C. - Wilker, V. - Kappa, M. - Scheffler, F. - Scheffler, M.: Novel-type glass foams from preceramic polymers with embedded titania nanoparticles for photo-catalytic applications, Adv. Eng. Mater. 2011, in press.

[8] Schwartzwalder, K. - Somers, H. - Somers, A. V.: Method of making porous ceramic articles, US Patent no. 3.090.094, 1963.

[9] Vogt, U. F. - Györfy, L. - Herzog, A. - Graule, T. - Plesch, G.: Macroporous Silicon Carbide Foams for High Temperature Applications and Catalyst Supports, Journal of Physics and Chemistry of Solids, 68 (2007), pp. 1234-1238.

[10] Adler, J. - Teichgraeber, M. - Standke, G. - Jaunich, H. - Stoever, H. Stoetzel, R.: Open-Cell Expanded Ceramic with a High Level of Strength, and Process for the Production thereof, WO 97/45381, 1996.

[11] Colombo, P. - Griffoni, M. - Modesti, M.: Ceramic Foams from a Preceramic Polymer and Polyurethanes: Preparation and Morphological Investigations, J. Sol-Gel Sci. Technol. 13 (1998), pp. 195-199.

[12] Gambaryan-Roisman, T. - Scheffler, M. - Buhler, P. - Greil, P.: Processing of Ceramic Foam by Pyrolysis of Filler containing Phenylmethyl Polysiloxane, Ceram. Trans. 108 (2000), pp. 121-130.

[13] Zeschky, J. - Hoefner, T. - Arnold, C. - Weißmann, R. - Bahloul-Hourlier, D. - Scheffler, M. - Greil, P.: Polysilsesquioxane derived ceramic foams with gradient porosity, ActaMaterialia53 (2005), pp. 927-937.

[14] Sepulveda, P. - Binner, J.G.P.: Processing of cellular ceramics by foaming and in situ polymerisation of organic monomers, J. Eur. Ceram. Soc. 19 (1999), pp. 2059-2066.
[15] Garrn, I. - Reetz, C. - Brandes, N. - Kroh, L. W. - Schubert, H.: Clotforming: the use of proteins as binders for producing ceramic foams, J. Eur. Ceram. Soc. 24 (2004), pp. 579-587.

[16] Gonzenbach, U. T. - Studart, A. R. - Tervoort, E. - Gauckler, L. J.: Macroporous Ceramics from Particle-Stabilized Wet Foams, J. Am. Ceram. Soc. 90 (2007), pp. 16-22.

[17] Komarneni, S. - Pach, L. - Pidugu, R.: Porous-alumina ceramics using bohemite and rice flour, Mater. Res. Soc. Symp. Proc. 371 (1995), pp. 285-290.

[18] Lemos, A. F. - Ferreira, J. M. F.: Porous bioactive calcium carbonate implants processed by starch consolidation, Mater. Sci. Eng. C11 (2000), pp. 35-40.

[19] Colombo, P. - Bernardo, E. - Biasetto, L.: Novel microcellular ceramics from a silicone resin, J.Am. Ceram. Soc. 87 (2004), pp. 152-154.

[20] Kleebe, H. J. - Turquat, C. - Sorarú, D.: Phase Separation in an SiOC Glass Studied by Transmission Electron Microscopy and Electron Energy-Loss Spectroscopy, J. Am. Ceram. Soc., 84 (2001), pp. 1073-1080.

Ref.: http://dx.doi.org/10.14382/epitoanyag-jsbcm.2011.10 Verena Reschke - Alexandra Laskowsky - Mathias Kappa - Kaishi Wang - Rajendra K. Bordia - Michael Scheffler: Polymer derived ceramic foams with additional strut porosity. Építöanyag, 63. évf. 3-4. szám (2011), 57-61. p.

Polimer alapú, növelt porozitású kerámia habok Növelt porozitású kerámia habokat állítottunk elố poliszilszeszkvioxán önhabosodási folyamatával. A porozitást az önhabzó szilikonhoz további pórusképzôt, nevezetesen poli(metilmetakrilátot) vagy polietilént adagolva növeltük meg. A polimer saját belsô zsugorodását úgy csökkentettük, hogy a kiindulási szilikon-polimer elegybe SiC részecskéket tartalmazó töltôanyagot kevertünk. A habosítást $270^{\circ} \mathrm{C}$-ra előmelegített kemencében végeztük. Ezt követôen az anyagot argon atmoszférában, $800-1200$ C közötti hômérsékleten pirolizáltuk a poliszilszeszkvioxán kerámiai anyaggá történô átalakítása céljából. Meghatároztuk a termékek pórusméretét és teljes porozitását, vizsgáltuk mikroszerkezetüket és mechanikai szilárdságukat. A termékek térfogat szerinti átlagos pórusmérete 25 és 100 um között, porozitása 40 és 94\% között változott. A legnagyobb mért nyomószilárdság $16 \mathrm{MPa}$ felett volt. Kulcsszavak: kerámia habok, prekerámia polimerek, önhabosodási folyamat, növelt hatású pórusképzôk

A 2002. június 13-án megnyitott Magyar Perlit Története állandó kiállitás a MTESZ Fố utcai székházának bezárását követốen jelenlegi formájában megszūnik. A kiállitás anyagának gondozását várhatóan Pálháza Város Polgármesteri Hivatala, a Budapesti Múszaki és Gazdaságtudományi Egyetem, a Perlit '92 Kft., a Cemkut Kft., a Mineralholding Kft. és a Perlit Fejlesztési Alapítvány veszik át.

További információ kérhetố a Szilikátipari Tudományos Egyesület titkárságán (tel./fax: 06-1/201-9360, email: info@szte.org.hu), valamint dr. Rudnyánszky Páltól (tel./fax: 06-1/329-8189).

2012-ben lesz 15. éve, hogy 1997. december 16-án Munkácson megnyitották a Rákóczi és Petôfi emlékszobákat. Az évforduló megünneplésének előkészitését megkezdte az SZTE Szigetelō Szakosztálya.

Elhunyt Hartmann Tibor (1924-2011) a Szilikátipari Tudományos Egyesület örökös tagja.

Emlékét ôrizzük. 